\title{
Climate Change - Analysis of Indicators
}

\author{
Robert Muszyński, Katarzyna Kocur-Bera* \\ University of Warmia and Mazury in Olsztyn, Poland
}

Received 03 February 2020; accepted 24 March 2020

\begin{abstract}
Progressing climate change poses a major threat to the Earth. According to a UN report, reducing global warming to below $1.5{ }^{\circ} \mathrm{C}$ offers hope for maintaining the current quality of human lives and for protecting the environment. The report also points out that there is a prescription for curbing the catastrophic effects of climate change. In order to achieve the aim of stopping the increase in temperature, both adequate knowledge of the hazard and measures based on proven technologies are required. The first step that will enable the commencement of activities is to identify the hazard characteristics and their effect on the environment. In this regard, various types of indicators that cover the local, regional and global scale in various aspects, both environmental and anthropogenic, are very helpful. The main purpose of the analysis is to examine indicators/indices that synthetically express/define various aspects which reflect climate change. The study applied the method of research of the available literature. The analysis showed that the economies of countries use indicators that describe the different scale of impact and a different objective and subjective range. This is mainly determined by the needs and accessibility of data.
\end{abstract}

Keywords: land management, globe protection, indicators of climate change.

\section{Introduction}

Sustainable development of the society is based on climatic conditions. The industrial revolution that took place 200 years ago began to significantly affect the natural environment (IPCC, 2012). Since then, many climate changes have been observed. Nowadays, this is a global problem which has attracted the attention of politicians, scientists, researchers and the general public worldwide. Scientists argue that the adaptation to the changing climate should be in line with the regional and local conditions. It is necessary to build on the analysis of relationships between climate change types and the related extreme events and hazards to the environment (Shi et al., 2016).

The traditional classifications and patterns of climatic regionalisation (Köppen, 1936; Thornthwaite, 1948; Strahler, 1975) that characterise the state of the climate have been developed on the basis of climate variables over a period of time. Currently, climate change is progressing and accelerating, and archival studies are not able to reflect its current trends. In the previous century, the main indicator of climate change was global warming; however, the trend for temperature increase varied considerably. The results differed significantly in regions at high latitudes and equatorial areas, and the average temperature in the Andes and South America was decreasing. Other indicators that characterise climate change, including precipitation, evapotranspiration, wind speed, etc. also demonstrated regional differentiation models, and the features were more complex (Ji et al., 2014; Wu et al., 2011; Hansen et al., 2010). Therefore, depending on the region, a particular indicator will more or less reflect climate change. A set of indicators should be selected for a specific region in order to indicate the occurring changes as accurate as possible.

In 2015, a UN world conference was held, which established a framework for the risk of natural disasters in the years 2015-2030. Despite a significant risk reduction at the local, national, regional and global level, the damage caused by natural disasters or hazards has increased. Despite the vast knowledge and state-of-the-art technology (risk mapping, risk assessment, satellites, early warning, geographical information system [GIS] and construction techniques, remote sensing), disasters continue to occur. When faced with a problem, it is important to develop a framework for risk and vulnerability assessment in order to help understand the natural risk and hazard as well as the potential impact of climate change on the society at the local, national, regional and global level (Queiroz de Almeida, 2016). According to research results, in the natural hazard department, it is not only the extreme events that result in a disaster but, above all, the conditions of societies exposed to hazards, which determine whether a natural phenomenon can cause a disaster or not.

\footnotetext{
${ }^{*}$ Corresponding author. E-mail: katarzyna.kocur@uwm.edu.pl
}

\section{Copyright (C) 2020 The Author(s). Published by VGTU Press}

This is an Open Access article distributed under the terms of the Creative Commons Attribution License (http://creativecommons.org/licenses/by/4.0/), which permits unrestricted use, distribution, and reproduction in any medium, provided the original author and source are credited. 
The Intergovernmental Panel on Climate Change report (IPCC, 2013) concludes that the global warming taking place worldwide since the mid-20th century has been caused by greenhouse gas emissions related to human activities, and particularly to combustion of fossil fuels, agriculture and all changes in land use. Greenhouse gas emissions must be reduced if the world is to avoid the most adverse climate changes. Unfortunately, even with a significant reduction in emissions, the climate will continue to change and the effects will be experienced throughout the planet. All changes have a variety of impacts on health, ecosystems and the economy. The effects of climate change are intensified by interactions with other factors such as e.g. changes in land use. Scientists believe that these impacts will be felt more over the next decades, and the effects will be more severe (EEA, 2017).

The main aim of this study was to examine the indicators which reflect and define various aspects of climate change. The study analysed the selection of appropriate indicators for a specific region and presents a variety of indicators based on the research area, the needs of the study or the target group. The paper also analysed the indicators selected by climate change research organisations. The analysis involved a review of the available literature, conducted research and available studies on the changes occurring on our planet.

\section{Methods for determining climate change}

Currently, global warming is a phenomenon prevailing worldwide, which, according to scientists, is largely linked to human activities (Solomon et al., 2007; Kocur-Bera, 2016). Politicians and organisations concerned with climate change have a difficult task to fulfil, considering such a large international heterogeneity of climate change hazards. They need to take into account all of the factors affecting this change. Many countries around the world are struggling to reduce greenhouse gas emissions. Reducing emissions in the years to come is a great challenge to climate policy. If the world does not start to act collectively and the high-emitting countries do not change their existing policies, the countries that reduce emissions will not benefit from these reductions. An agreement on this matter is determined by the costs, advantages and adverse effects linked to climate change for a particular country. The differences in national exposure to climate change are significant and of crucial importance. In order to determine vulnerability indicators, even within a particular region, it does not suffice to take into account socio-economic variables; it is necessary to analyse the interactions between these variables and the heterogeneity of physical climate change (Diffenbaugh et al., 2005). This, unfortunately, does not solve every problem or provide an answer to each question related to climate change. No set of indicators is available to fit every problem and all regions on the planet (Diffenbaugh et al., 2007).

Climate change can be divided into nine modes based on the tendencies (rise, decline, not significant) and fluctuations (rise, decline, not significant) of climate variables (Shi et al., 2016). The modes of change are shown in the figure below (Figure 1).
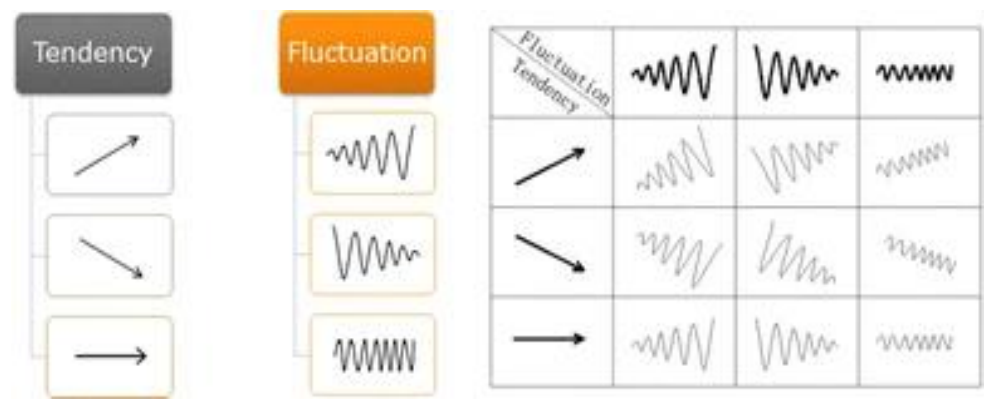

Figure 1. Modes of climate change (source: Shi et al., 2016)

The average surface temperature is constantly rising; currently, it is higher by $1{ }^{\circ} \mathrm{C}$ than the temperatures of the pre-industrial era. If the greenhouse gas emissions are not reduced, the temperature is projected to increase by $1.5^{\circ} \mathrm{C}$ in 2030 , and by more than $4{ }^{\circ} \mathrm{C}$ by the year 2100 . There are no good forecasts for future generations either, as this increase is going to be up to three times higher in the years to come (Popkiewicz, 2018).

The above diagram (Figure 2) illustrates the annual and long-term changes in air temperature since 1979. All values are differences in relation to climatic norms of 1981-2010. The differences are most evident at high latitudes

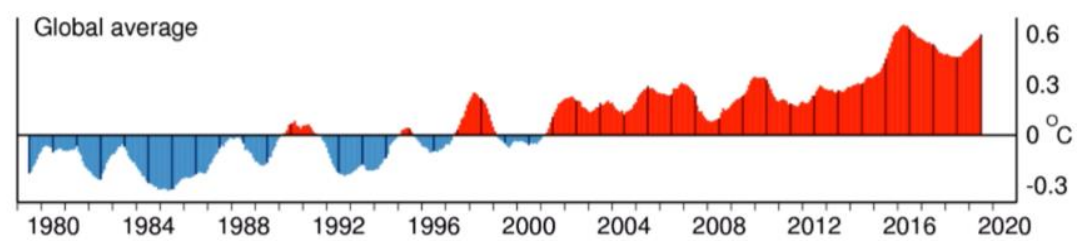

Figure 2. Year-to-year variations and longer-term changes in surface air temperature since 1979 (source: Climate Change Service, https://climate.copernicus.eu) 
where surface temperatures are sensitive in winter to the presence of ice cover at the sea and snow cover on land. In recent years in the Arctic, conditions much warmer than the average ones have been noted. In Antarctica, the general trend is minor. The greatest differences are found in the Tropical Eastern Pacific.

Climate warming can be identified not only from temperature readings but also from many other measurements and processes occurring on the planet. Besides the thermometer, indicators may include the following:

- glacier shrinkage,

- the occurrence of trees and animals at higher altitudes,

- growing period,

- snow cover,

- sea level,

- humidity level,

- sea surface temperature,

- sea ice,

- heat content in the ocean,

- air temperature near the surface (troposphere).

There are also a number of other indicators which measure climate change; their use or a failure to do so is determined by a subjective assessment by an author of a particular study (Popkiewicz, 2011).

As previously mentioned, there are many indicators besides temperature that help calculate climate change. A set of indicators that characterise this change should indicate the range and rate of climate change. There are numerous different sets of global climate indicators presented by various organisations; however, many of them have been compiled for specific purposes and target groups. Their selection depends on decision-makers and stakeholders. However, each indicator should meet the following criteria:

- Validity: each indicator should have a broad audience and be understandable, and should clearly indicate global climate change. Some indicators will have national or regional values.

- Representativeness: a set of indicators should provide a representative picture of changes occurring within the Earth system.

- Traceability: calculations should be based on an internationally accepted and published method.

- Punctuality: calculations should be carried out regularly, at least once a year, and the results should be published as soon as calculations are completed.

- Limited number: in order to obtain clear and understandable information, the number of indicators should be limited, and the use of a particular indicator should be justified.

According to the WMO experts, the indicators identified at the global level should not be taken into account in an expert analysis at the local level. Global data may interfere with the accuracy of the indication of a specific local problem. An important component in determining climate change is the indication of main groups of indicators in order to ensure consistent reporting. In each of the groups, more detailed indicators are defined to obtain extended reports and auxiliary data sets. This provides us with more information while taking into account various aspects and trends in climate change. The indicators are based on multiple different sources of information. Consequently, they include various past and future periods, and the information is presented at various levels of regional aggregation.

The figure below (Figure 3) presents a selection of key impacts and vulnerabilities for the main biogeographical regions in Europe. The presented list shows the various consequences of climate change. As a result, each of the presented regions will face different problems and difficulties to overcome. In this case, it is important to precisely identify the trend in the changes and to predict their impact on the environment and society. In order to determine these changes, it is necessary to generate an appropriate set of climate change indicators which correspond to the problems and hazards in a particular area. The figure below shows how incorrect it would be to determine climate change only through the globally accepted indicators.

\section{Analysis of climate change indicators}

During a WMO meeting in December 2016, the indicators assigned to the following groups were discussed and agreed upon:

- temperature and energy,

- atmospheric composition,

- cryosphere

- ocean,

- land use,

- length of the growing period,

- extreme events,

-impact on humans. 


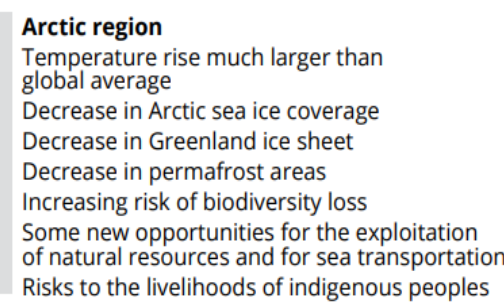

\section{Coastal zones and regional seas}

Sea level rise

Increase in sea surface temperatures

Increase in ocean acidity

Northward migration of marine species

Risks and some opportunities for fisheries

Changes in phytoplankton communities

Increasing number of marine dead zones

Increasing risk of water-borne diseases

\section{Atlantic region}

Increase in heavy precipitation events Increase in river flow

Increasing risk of river and coastal flooding Increasing damage risk from winter storms Decrease in energy demand for heating Increase in multiple climatic hazards

\author{
Mediterranean region \\ Large increase in heat extremes \\ Decrease in precipitation and river flow \\ Increasing risk of droughts \\ Increasing risk of biodiversity loss \\ Increasing risk of forest fires \\ Increased competition between different water users \\ Increasing water demand for agriculture \\ Decrease in crop yields \\ Increasing risks for livestock production \\ Increase in mortality from heat waves \\ Expansion of habitats for southern disease vectors \\ Decreasing potential for energy production \\ Increase in energy demand for cooling \\ Decrease in summer tourism and potential increase in other seasons \\ Increase in multiple climatic hazards \\ Most economic sectors negatively affected \\ High vulnerability to spillover effects of climate change \\ from outside Europe
}

Boreal region

Increase in heavy precipitation events Decrease in snow, lake and river ice cover Increase in precipitation and river flows

Increasing potential for forest growth

and increasing risk of forest pests

Increasing damage risk from winter storms

Increase in crop yields

Decrease in energy demand for heating

Increase in hydropower potential

Increase in summer tourism

Figure 3. Key observed and projected climate change and impacts for the main biogeographical regions in Europe (source: EEA, 2017. Climate change, impacts in Europe 2016)

For each group, a leading indicator and auxiliary indicators providing additional information were identified. During the meeting, it was determined that these were groups defined at the global level. General indicators assigned in specific groups cannot solve particular adaptation problems which are locally specific. This is only an outline of the research area, and each problem and research area need to be approached on an individual basis. The process of establishing the best indicators should not be guided by ready-made solutions but should apply appropriate methodologies and studies. The crucial issue is the access to (and selection of) appropriate scientific data and relevant information. Specific data-based indicators must be reliable and should fulfil their intended purpose. Sometimes there are several different data sets for a particular indicator. Pieces of information about similar trends can reinforce each other and offer a better insight into the problem (GCOS, 2017).

The World Meteorological Organization (WMO) is an international organisation with 193 member states. WMO is a specialised United Nations agency for weather and climate, operational hydrology and related geographical sciences. The WMO climate data catalogue is a reliable source of climate data. Data sets have been agreed upon at the international level. The database is expanding and becoming increasingly popular at the regional and national level (https://public.wmo.int/en/about-us). During a meeting organised by the WMO in 2017, organisations working on climate indicators were presented (1-17):

1. World Climate Research Programme (WCRP).

2. World Meteorological Organization (WMO).

3. Copernicus Climate Change Service (C3S).

4. IGBP since 2015, now Future Earth.

5. National Aeronautics and Space Administration (NASA).

6. Environmental Protection Agency (EPA).

7. National Oceanic and Atmospheric Administration (NOAA). 
8. Bulletin of the American Meteorological Society (BAMS) cooperation with NOAA.

9. European Environment Agency.

10. United Nations Environment Programme / Global Environment Outlook (UNEP/GEO).

11. UNEP grid Environmental Data Explorer.

12. The Intergovernmental Panel on Climate Change (IPCC).

13. GERMANWATCH (Global Climate Risk index).

14. The Ocean Observations Panel for Climate (OOPC) (State of the ocean indices).

15. Notre Dame Global Adaptation Index.

16. Climate Change Health Indicators EPA.

17. Eurostat Climate Change and Energy indicators.

Each organisation's areas of activity are presented in the summary table (Table 1) provided in Appendix 1. Each organisation has established individual indicators tailored to its own research area. There is a group of indicators that are characteristic of a particular research group, while others are taken into account in almost every analysis. Therefore, the indicator most frequently used by climate research organisations is the sea level (applied in 13 out of 17 studies). The temperature-related indicators are equally often used (temperature [increase] or global temperature (Kocur-Bera, 2019) + surface temperature (Diffenbaugh et al., 2007). Almost 53\% of studies regarded sea ice and ice melting as a significant indicator affecting climate change. Other frequently (seven times) used indicators include precipitation, land ice and glaciers, and ocean warming. Other data commonly used to determine climate change included greenhouse gas emissions, carbon dioxide concentration, methane emissions and ocean change indicators (e.g. acidification). Certain studies which addressed vulnerability to climate change analysed socio-economic effects and consequences for humanity (Kocur-Bera, 2016, 2019). Particular organisations used in their studies various amounts of indicators (4-37), with some of them fulfilling supplementary or auxiliary tasks for the main indicators. For example, the Environmental Protection Agency uses 37 indicators which are allocated to six main groups: Greenhouse Gases, Weather and Climate, Oceans, Snow and Ice, Health and Society, and Ecosystems. On the other hand, the National Aeronautics and Space Administration uses five main parameters (carbon dioxide concentration, global temperature, arctic sea ice, land ice and sea level) on which its research is based. In summary, there are indicators which are reflected in most regions worldwide, e.g. the sea level or temperature increase. There are also unique indicators whose application is justified only in specific areas where reliable data are found that enable the determination of the climate change trend.

\section{Conclusions}

The progressing climate change poses a serious hazard to the Earth and its inhabitants. Weather anomalies and extreme events that bring about increasingly severe consequences, despite the universal availability of advanced technologies and extensive research in this area, are occurring with an increasing frequency. It is not necessary to go far in the past to find a reflection of this statement in reality. For a few months, the ongoing fires in Australia have ravaged ecosystems throughout the continent and killed numerous animal and plant species. The fire raging for many months has created its own weather. Fires in Australia are a natural and cyclical phenomenon. Climate change does not start fires but it dramatically intensifies them (Piekło Australii trwa, 2020). In order to protect the world from self-destruction, appropriate preventive measures need to be taken. The adaptation to the changing climate should be in line with the regional and local conditions. It is necessary to build on the analysis of relationships between climate change types and the related extreme events and hazards to the environment. Moreover, the hazards arising from climate changes should be predicted, and plans for the prevention or minimisation of these hazards' effects should be developed. To achieve this, knowledge of hazards and means based on tested methods and technologies are required. The first step is to collect available data and to identify the properties of hazards and their impact on the environment in a particular area. During the analysis, various types of indicators appropriate for the local, national, regional and global level are helpful.

This study conducted an analysis of the literature and available studies in terms of the climate change indicators used and the methods for their determination. The aim of the study was not to show the exhaustive number of indicators affecting the climate change index but to demonstrate the complexity of the process of selection of indicators appropriate for the problem concerned and the area under study. There are many indicators which enable the determination of the trend in climate change, yet it is their selection that contributes to the quality and reliability of the obtained results. The process of establishing the best indicators should not be guided by ready-made solutions but should apply appropriate methodologies and studies.

The conducted analysis reveals that no single set of indicators for the entire world exists. Depending on the organisation examining climate change, the indicators are different. There are indicators used in almost every region while others are unique for a particular area. The frequently used indicators include sea level and temperature. The indicators equally popular in scientific studies include the precipitation, land ice and glaciers, ocean warming, greenhouse gas emissions and carbon dioxide concentration. Depending on the needs, experts use various numbers of indicators; some of them are more general, while others are more detailed and supplement the research area. The selection of indicators is not arbitrary; it must be properly justified, and the obtained data for their determination need 
to be derived from a reliable source. A set of an appropriate group of indicators offers a better chance for more accurate clarification of the problem, which determines the selection of an indicator used for space management.

\section{References}

Climate Change Service. (2020). The Copernicus Programme. Retrieved 08 January, 2020, from https://climate.copernicus.eu

Diffenbaugh, N., Pal, J., Trapp, R., \& Giorgi, F. (2005). Fine-scale processes regulate the response of extreme events to global climate change. Proceedings of the National Academy of Sciences of the USA (PNAS), 102(44), 15774-15778. https://doi.org/10.1073/pnas.0506042102

EEA. (2017). Climate change, impacts and vulnerability in Europe 2016. Retrieved 08 January, 2020, from https://www.eea.europa.eu/publications/climate-change-impacts-and-vulnerability-2016

GCOS. (2017). Indicators of Climate Change. Outcome of a meeting held at WMO 3 February 2017. Retrieved 02 January, 2020, from https://library.wmo.int/doc_num.php?explnum_id=3418

Hansen, J., Ruedy, R., Sato, M., \& Lo, K. (2010). Global surface temperature change. Reviews of Geophysics, 48(4), 1-29. https://doi.org/10.1029/2010RG000345

IPCC (Intergovernmental Panel on Climate Change). (2012). IPCC special report on managing the risks of extreme events and disasters to advance climate change adaptation. Retrieved January 08, 2020, from https://wg1.ipcc.ch/srex/downloads/SREX-All_FINAL.pdf

IPCC (Intergovernmental Panel on Climate Change). (2013). IPCC climate change 2013: The physical science basis. Cambridge University Press. Retrieved January 10, 2020, from https://www.ipcc.ch/site/assets/uploads/2018/03/WG1AR5_SummaryVolume_FINAL.pdf

Ji, F., Wu, Z., Huang, J., \& Chassignet, E. (2014). Evolution of land surface air temperature trend. Nature Climate Change, 4, 462466. https://doi.org/10.1038/nclimate2223

Kocur-Bera, K. (2016). Kształtowanie bezpiecznej przestrzeni obszarów wiejskich waspekcie występowania ekstremalnych zjawisk pogodowych. UWM Olsztyn.

Kocur-Bera, K. (2019). Vulnerability of rural areas to climate change - analysis of similar units in terms of spatial conditions for Warmińsko-Mazurskie Voivodeship. Journal of Ecological Engineering, 20(6), 198-206. https://doi.org/10.12911/22998993/109454

Köppen, W. (1936). The geographical system of climates [Das geographische system der climate]. In Handbook of climatology [Handbuch der klimatologie], W. Köppen \& R. Geiger (Eds.), 1-44. Berlin: Gebrüder Borntraeger.

Piekło Australii trwa - katastrofa klimatyczna to też nasza rzeczywistość. (2020). Retrieved 02 January, 2020, from https://www.wwf.pl/aktualnosci/pieklo-australii-trwa-katastrofa-klimatyczna-tez-nasza-rzeczywistosc

Popkiewicz, M. (2011). Wskaźniki zmiany klimatu. Retrieved January 02, 2020, from https://ziemianarozdrozu.pl/artykul/1709/grafika-dnia-wskazniki-zmiany-klimatu

Popkiewicz M., $2018,1,5^{\circ} \mathrm{C} \ldots 2^{\circ} \mathrm{C} \ldots 3^{\circ} \mathrm{C} \ldots 4^{\circ} \mathrm{C}$ - Porównanie następstw zmiany klimatu. Retrieved January 10,2020 , from https://naukaoklimacie.pl/aktualnosci/porownanie-nastepstw-zmiany-klimatu-306

Queiroz de Almeida, L., Welle, T., \& Birkmann, J. (2016). Disaster risk indicators in Brazil: A proposal based on the world risk index. Elsevier. https://doi.org/10.1016/j.ijdrr.2016.04.007

Shi, P., Sun, S., Gong, D., \& Zhou, T. (2016). World Regionalization of Climate Change (1961-2010). International Journal of Disaster Risk Science, 7, 216-226. https://doi.org/10.1007/s13753-016-0094-5

Solomon, S., Qin, D., Manning, M., Marquis, M., Averyt, K., Miller, H. L., \& Chen, Z. (2007). Climate change 2007: The physical science basis. Intergovernmental Panel on Climate Change Working Group. Cambridge Univ Press.

Strahler, A. N. (1975). Classification of global climates. In A. N. Strahler (Ed.), Physical geography (pp. 243-245). John Wiley.

Thornthwaite, C. W. (1948). An approach toward a rational classification of climate. Geographical Review, 38(1), 55-94. https://doi.org/10.2307/210739

WMO. (2017). World Meteorological Organization. Retrieved January 02, 2020, from https://public.wmo.int/en/about-us

Wu, Z., Huang, N., Wallace, J., Smoliak, B., \& Chen, X. (2011). On the time-varying trend in global-mean surface temperature. Climate Dynamics, 37, 759-773. https://doi.org/10.1007/s00382-011-1128-8 


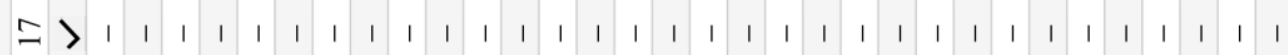

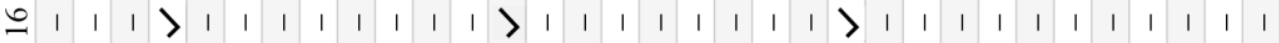

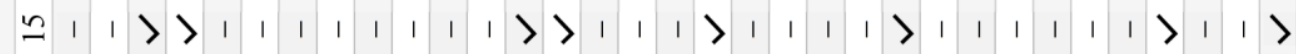

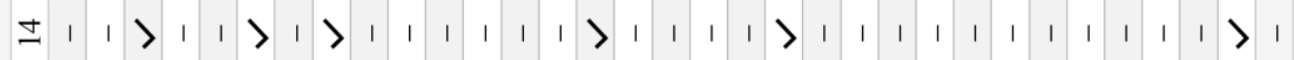

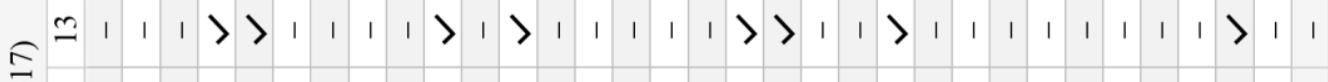

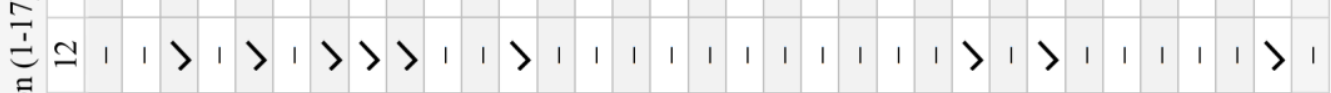

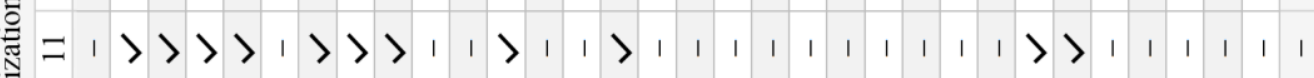

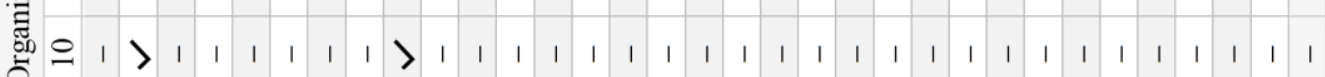
궁

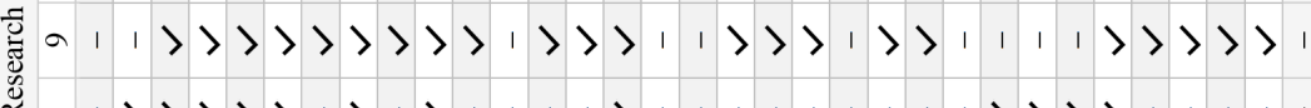

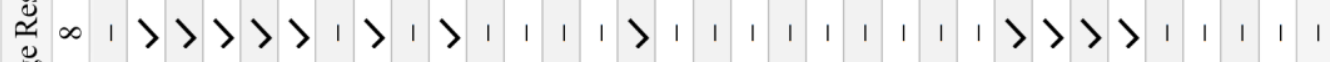

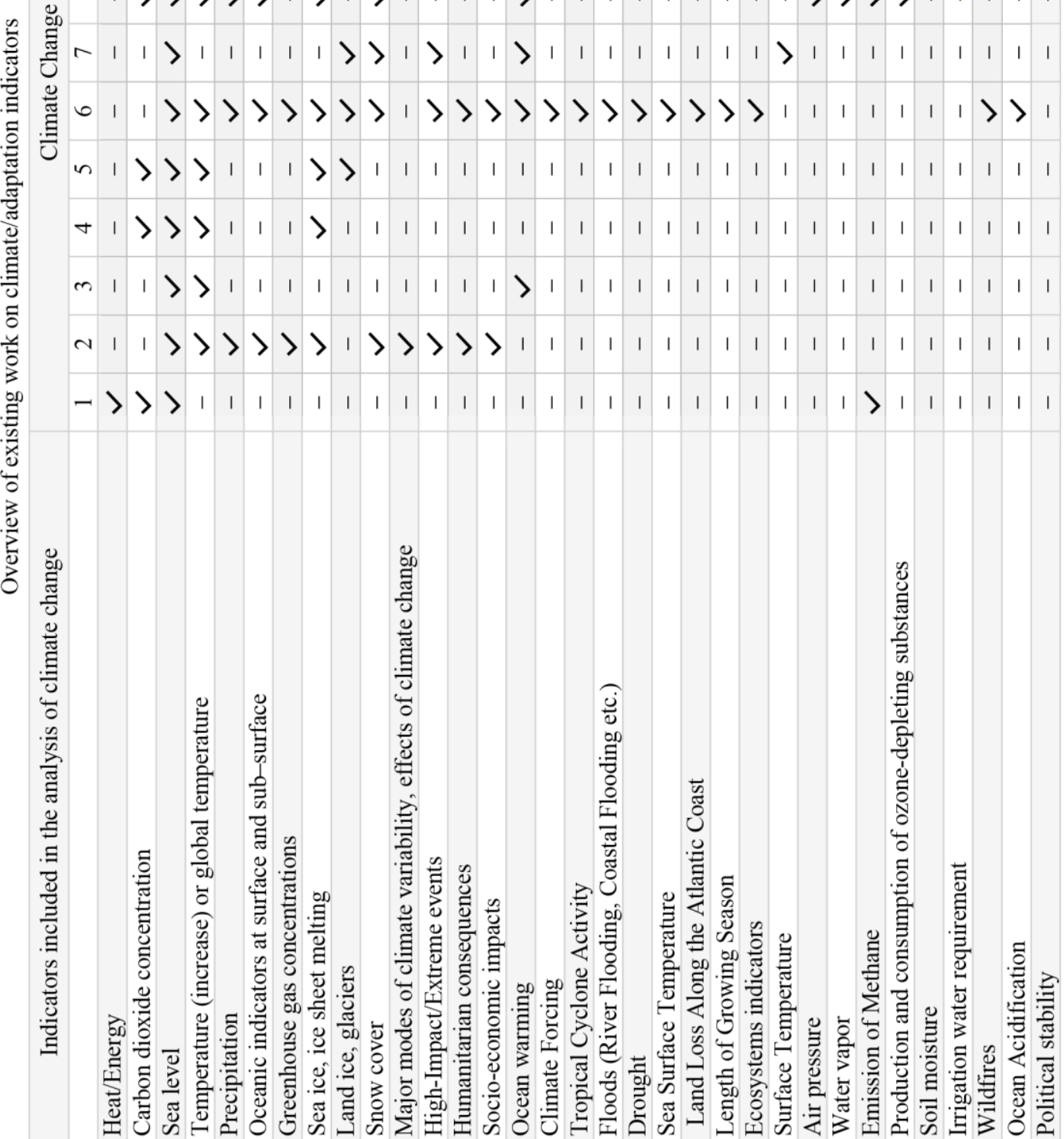

